Research Article

\title{
An assessment of effect of national rural health mission on newborn care practices in Bangalore rural area
}

\author{
Narasimha B. C. ${ }^{1}{ }^{*}$, Ravish K. S. ${ }^{2}$, Ranganath T. S. ${ }^{3}$, Manjula K. ${ }^{1}$, Spoorthy S. ${ }^{1}$, Navya S. S. ${ }^{1}$
}

${ }^{1}$ Post graduate student, ${ }^{2}$ Assistant Professor, ${ }^{3}$ Professor and Head, Department of Community Medicine, Bangalore Medical College \& Research Institute, Bengaluru, India

Received: 27 July 2016

Accepted: 02 August 2016

*Correspondence:

Dr. Narasimha BC,

E-mail: narasimhabc@yahoo.co.in

Copyright: ( ) the author(s), publisher and licensee Medip Academy. This is an open-access article distributed under the terms of the Creative Commons Attribution Non-Commercial License, which permits unrestricted non-commercial use, distribution, and reproduction in any medium, provided the original work is properly cited.

\section{ABSTRACT}

Background: Despite efforts by the government and other agencies, neonatal morbidity and mortality continues to be high in India. Among other reasons, Newborn care practices are major contributors for such high rates.

Methods: Community based, cross sectional study was done in the rural field practice area covered under Primary Health Centre, Hesaraghatta, and Bengaluru rural. A semi structured, pre-tested questionnaire was used to interview 160 mothers of the newborns in the study area.

Results: 160 mothers were interviewed at their home within 15 days of delivery. All the mothers (100\%) had registered at the time of pregnancy, received prescribed doses of tetanus toxoid and Iron folic acid (IFA) tablets. 160 study participants underwent institutional deliveries. Among all the deliveries sterile blade and sterile cord clamp was used for cord care. Immediate bath was given to $2.5 \%$ of cases. About $62.5 \%$ of the mothers initiated breast feeding within 1 hour and colostrum was fed to $95.6 \%$ of babies. About $137(85.6 \%)$ babies were immunized up to date.

Conclusions: Irrespective of the educational and socio-economic status of the mothers there were $100 \%$ institutional deliveries in our rural field practice area. This is because of various Maternal and Child Health $(\mathrm{MCH})$ related schemes under National Rural Health Mission (NRHM) to reduce maternal and neonatal mortality by increasing institutional deliveries.

Keywords: Newborn care, National Rural Health Mission, Institutional deliveries, Tetanus toxoid, Iron folic acid, Breast feeding, Colostrum

\section{INTRODUCTION}

Healthy children are the greatest resource and pride of a nation. Investment in child development is an investment in the future of the nation. ${ }^{1}$ The first 28 days life of neonatal period is the most vulnerable time for a child's survival. Every year, about 2.8 million newborns die within 1 month of birth and half of them die within 24 hours after birth. Of these, $98 \%$ of deaths occur in developing countries. Newborn deaths now contributes to about $44 \%$ of all deaths in children under 5 years of age globally. $^{2}$
As depicted in Figure 1, neonatal deaths results from diseases and conditions that are readily preventable or treatable with proven, cost effective interventions like essential newborn care. $^{2}$

According to World Health Organization, essential newborn care encompass cleanliness, thermal protection, initiation of breathing, early and exclusive breast feeding, eye care, immunization, management of illness, and the care of low birth weight infants. ${ }^{3}$ 
Though the under-five and infant mortality rates have declined over the past four decades, the neonatal mortality rates have remained relatively unchanged. This is the sufficient evidence to say that most of the basic neonatal care which is delivered through primary care is highly cost-effective and need to give more importance. ${ }^{4}$ Hence we have conducted a study in rural area to assess Newborn care practices.

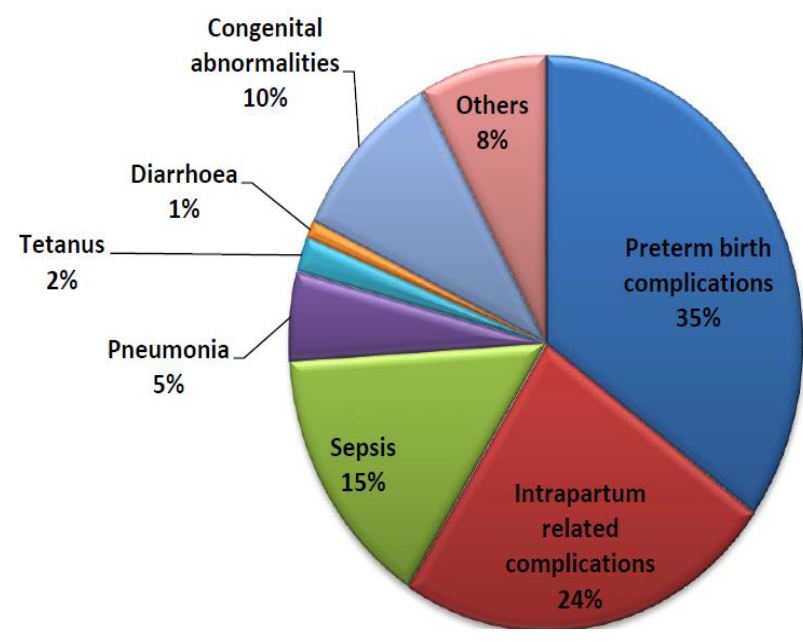

Figure 1: Causes of neonatal death.

\section{METHODS}

A community based cross sectional study in rural area (Hesarghatta), from October 2013 to September 2014.

Study population: Live births occurring during the study period

Study sample size: The sample size of 160 was decided for this study bases on previous prevalence.

Under Primary health centre of Hesaraghatta, there are 4 sub-centres and 27 Anganwadi centres. Out of these, 3 Anganwadi centres were selected from each sub-centre by simple random sampling method. All the deliveries in the selected Anganwadi centres during the study period were used for data collection till the desired sample size reached. Information regarding recent deliveries was collected using a pretested semi structured questionnaire within 15 days of delivery.

\section{RESULTS}

Totally 160 mothers were interviewed at their home and the mean age of mothers were $23.15+3.1$ years. Among $160,47.5 \%$ of mothers were educated till high school level and $96.3 \%$ of mothers were home makers. $73.1 \%$ of the mothers belonged to "Class I" socio-economic status. The mean age of marriage among the study participants were $19.1+2.14$ years; almost half of the mothers $(48.1 \%)$ had delivered their second child. All the mothers had registered their pregnancy and $91.2 \%$ of the mothers had $\geq 4$ antenatal visits. $81.9 \%$ of mothers had received 2 doses of tetanus toxoid. All 160 (100\%) women had underwent institutional delivery by a trained personnel (Table $1 \&$ 2).

Table 1: Distribution of mothers according to age \& socio-economic status.

\begin{tabular}{|lll|}
\hline $\begin{array}{l}\text { Age of the mothers } \\
\text { (In years) }\end{array}$ & No. of mothers (n) & Percentage \\
\hline $18-22$ & 77 & $48.2 \%$ \\
\hline $23-27$ & 73 & $45.6 \%$ \\
\hline$>28$ & 10 & $6.2 \%$ \\
\hline Total & $\mathbf{1 6 0}$ & $\mathbf{1 0 0 \%}$ \\
\hline Class & No. of mothers (n) & Percentage \\
\hline Class I & 117 & $73.1 \%$ \\
\hline Class II & 34 & $21.3 \%$ \\
\hline Class III & 9 & $5.6 \%$ \\
\hline Total & 160 & $100 \%$ \\
\hline
\end{tabular}

Table 2: Distribution of mothers according to parity \& numbers of antenatal visits.

\begin{tabular}{|lll|}
\hline Parity & No. of mothers & Percentage \\
\hline 1 & 68 & $42.5 \%$ \\
\hline 2 & 77 & $48.1 \%$ \\
\hline 3 & 15 & $9.4 \%$ \\
\hline Total & 160 & $100 \%$ \\
\hline Antenatal visits & No. of Mothers & Percentage \\
\hline <4 ANC visits & 14 & $8.8 \%$ \\
\hline $\begin{array}{l}\text { 4 \& above ANC } \\
\text { visits }\end{array}$ & 146 & $91.2 \%$ \\
\hline Total & 160 & $100 \%$ \\
\hline
\end{tabular}

Table 3: Distribution of mothers according to number of iron and folic acid tablets taken $\&$ delivery practices.

\begin{tabular}{|ll|l|}
\hline IFA tablets & No. of Mothers & Percentage \\
\hline Below 100 & 74 & $46.3 \%$ \\
\hline 100 & 78 & $48.7 \%$ \\
\hline Above 100* & 8 & $5 \%$ \\
\hline Total & 160 & $100 \%$ \\
\hline Place of delivery & No. of Mothers & Percentage \\
\hline Home & Nil & Nil \\
\hline Institutional & 160 & $100 \%$ \\
\hline Total & 160 & $100 \%$ \\
\hline Delivery conducted by & \\
\hline Trained personnel & 160 & $100 \%$ \\
\hline Total & 160 & $100 \%$ \\
\hline Nature of delivery & & \\
\hline LSCS & 42 & $26.2 \%$ \\
\hline Normal deliveries & 118 & $73.8 \%$ \\
\hline Total & 160 & $100 \%$ \\
\hline
\end{tabular}

The study revealed that $94.4 \%$ of the newborns were full term babies and $48.1 \%$ (77) were males and $51.9 \%(83)$ 
were female babies. The birth weight was recorded at the time of birth and it was found that $12.5 \%$ (20) of babies were low birth weight.

Table 4: Distribution of newborns according to their gestational age.

\begin{tabular}{|c|c|}
\hline Duration & Frequency (Percentage) \\
\hline Preterm & $7(4.4 \%)$ \\
\hline Term & $151(94.4 \%)$ \\
\hline Post term & $2(1.2 \%)$ \\
\hline Total & $160(100 \%)$ \\
\hline Sex of Newborn & Frequency (Percentage) \\
\hline Male & $83(51.9 \%)$ \\
\hline Female & $77(48.1 \%)$ \\
\hline Total & $160(100 \%)$ \\
\hline Birth weight (Kg) & Percentage \\
\hline$<2.5 \mathrm{Kg}$ & $12.5 \%$ \\
\hline $2.5 \mathrm{Kg} \&$ above & $87.5 \%$ \\
\hline Total & $100 \%$ \\
\hline
\end{tabular}

Table 5: Distribution of newborns according to the care given at birth.

\begin{tabular}{|ll|}
\hline Cleaning the air passage & Frequency (Percentage) \\
\hline Mucus extractor & $89(55.6 \%)$ \\
\hline Don't know & $71(44.4 \%)$ \\
\hline Total & $160(100 \%)$ \\
\hline Eye care & Frequency (Percentage) \\
\hline Sterile cotton & $79(49.4 \%)$ \\
\hline Don't know & $81(50.6 \%)$ \\
\hline Total & $160(100 \%)$ \\
\hline $\begin{array}{l}\text { Instrument used to cut } \\
\text { the cord }\end{array}$ & Frequency (Percentage) \\
\hline Sterile blade & $157(98.1 \%)$ \\
\hline Don't know & $3(1.9 \%)$ \\
\hline Total & $160(100 \%)$ \\
\hline Material used to tie cord & Frequency (Percentage) \\
\hline Sterile cord clamp & $158(98.7 \%)$ \\
\hline Don't know & $2(1.3 \%)$ \\
\hline Total & $160(100 \%)$ \\
\hline $\begin{array}{l}\text { Application on cord } \\
\text { stump }\end{array}$ & Frequency (Percentage) \\
\hline Yes & $0(0 \%)$ \\
\hline No & $77(48.1 \%)$ \\
\hline Not Applicable* & $83(51.9 \%)$ \\
\hline Keeping the baby warm & Frequency (\%) \\
\hline Yes & $158(98.8 \%)$ \\
\hline No & $2(1.2 \%)$ \\
\hline Total & $160(100 \%)$ \\
\hline Cleaning the body & Frequency (Percentage) \\
\hline Immediate Bath & $4(2.5 \%)$ \\
\hline Dry cloth & $151(94.4 \%)$ \\
\hline Don't know & $5(3.1 \%)$ \\
\hline Total & $160(100 \%)$ \\
\hline f cord was fallen of befo $)$ \\
\hline (15)
\end{tabular}

*if cord was fallen of before my visit
$44.4 \%$ (71) of the mothers did not know whether the respiratory passage was cleaned and50.6\% (81) of mothers were not aware of newborn eye care. Since all were institutional deliveries, sterile cord clamp and sterile blade were used for umbilical cord care. Only $2.5 \%$ of Newborns were washed with warm water immediately. Breast milk was given as the first feed in $94.4 \%$ of the babies, $62.5 \%$ of the mothers initiated breast feeding within $\leq 1$ hour and colostrum was fed to $95.6 \%$ of babies. About $85.6 \%$ (137) of babies were appropriately immunized.

In spite of $100 \%$ institutional deliveries, there are few harmful Newborn care practices prevailing in the community such as discarding of colostrum, delayed initiation of breastfeeding etc. as shown in Figure $2 \& 3$.

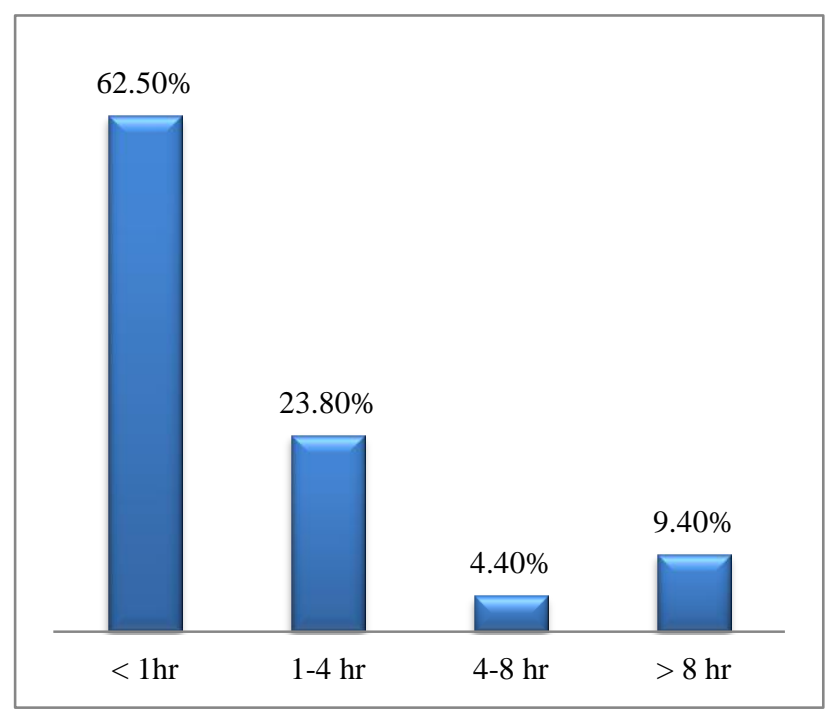

Figure 2: Time of Initiation of breast feeding.

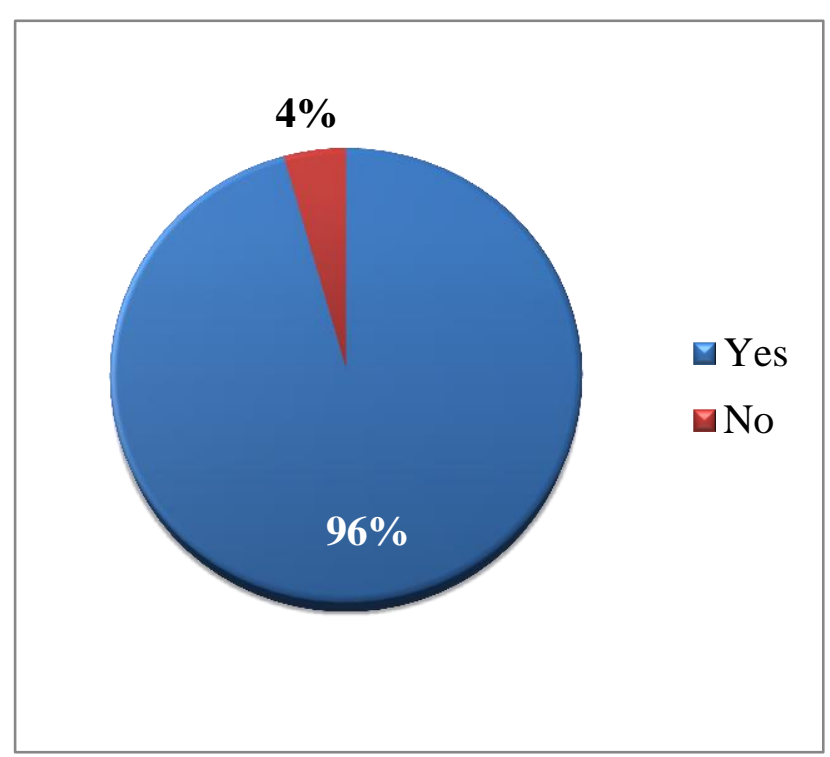

Figure 3: Colostrum given to newborn. 
Table 6: Distribution of newborns according to the immunization status.

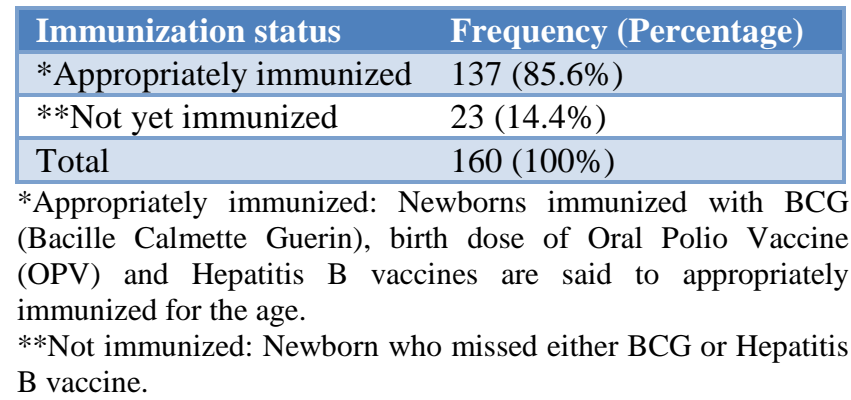

\section{DISCUSSION}

As shown in Table $1,48.2 \%$ of the mothers were in the age group of 18-22 years and only $6.2 \%$ were above 28 years. The mean age of mother was 23.15 years with standard deviation of 3.1. In a study by Chandrasekhar $\mathrm{T}$ et al the median age of the mothers was 24 years. ${ }^{5}$

Table 2 shows distribution of mothers according to their parity. Around $48.1 \%$ of the mothers were of second parity and $9.4 \%$ were of third parity. Study by Yasmin S et al revealed that $48 \%$ were primi parous and $3 \%$ had delivered their fifth child or higher. ${ }^{6}$

Table 2 shows that the mean number of antenatal visits was 6.57 and $91.2 \%$ of the mothers had $\geq 4$ antenatal visits; hence only $8.8 \%$ of the mothers had failed to take recommended minimum four antenatal visits. It was remarkable to note that all the mothers $(100 \%)$ had registered their pregnancy.

Among the mothers who had received IFA tablets only $48.7 \%$ had consumed 100 IFA tablets i.e. $46.3 \%$ had consumed less than 100 tablets (Table 3).Agarwal S et al. undertook a study in Indore, while $86.2 \%$ received iron and folic acid tablets and only $11.5 \%$ had consumed them. ${ }^{7}$

The results of the study show that $100 \%$ were institutional deliveries (table no 3), as against country's average of $41 \%$ according to NFHS-III. The following table shows institutional deliveries in India (NHFS-3), Karnataka \& Bengaluru rural (DLHS-4). ${ }^{8-10}$

The observations of this study revealed that most of the newborns $(94.4 \%)$ were full term babies, $4.4 \%$ were preterm and $1.3 \%$ were post-term (Table 4 ). In a study by Puri $\mathrm{S}$ et al. it was observed that Post term deliveries were more in urban area, $5.3 \%$ and $15 \%$ were pre term deliveries in slums. Proportion of mothers who delivered at full term was similar in urban and slum area. ${ }^{11}$

Table 4 shows that out of total 160 newborns $51.9 \%$ (83) were males and $48.1 \%$ (77) were females. In a study done by Gandhi SJ et al. in rural area of Navsari district. It was found that male $(51.4 \%)$ and female $(48.6 \%)$ children were almost in equal proportion. ${ }^{12}$

Table 7: Institutional deliveries in India, Karnataka and Bengaluru rural.

\begin{tabular}{|lll|}
\hline NFHS 3 & Karnataka-DLHS 4 & $\begin{array}{l}\text { Bengaluru } \\
\text { rural- DLHS 4 }\end{array}$ \\
\hline $41 \%$ & $89 \%$ & $97.1 \%$ \\
\hline
\end{tabular}

Table 8: Showing the few MCH indicators in India, Karnataka \& Rural Bengaluru.

\begin{tabular}{|llll|}
\hline Indicators & $\begin{array}{l}\text { India } \\
\text { (NFHS 3) }\end{array}$ & $\begin{array}{l}\text { Karnataka } \\
\text { (DLHS 4) }\end{array}$ & $\begin{array}{l}\text { Bengaluru } \\
\text { Rural } \\
\text { (DLHS 4) }\end{array}$ \\
\hline $\begin{array}{l}\text { Trained } \\
\text { personnel }\end{array}$ & $48.2 \%$ & $92.2 \%$ & $97.5 \%$ \\
\hline LSCS & $13.6 \%$ & $22.2 \%$ & $35.4 \%$ \\
\hline $\begin{array}{l}\text { Normal } \\
\text { delivery }\end{array}$ & $86.40 \%$ & 77.8 & $64.6 \%$ \\
\hline
\end{tabular}

The birth weight was recorded in all cases, out of which $12.5 \%$ (20) were low birth weight (Table 4) against national average of $22 \% .^{13}$

Table 9: Showing Prevalence of LBW in different sources.

\begin{tabular}{|llll|}
\hline $\begin{array}{l}\text { Source of } \\
\text { the data }\end{array}$ & $\begin{array}{l}\text { NFHS- } \\
\text { III }^{\mathbf{8}}\end{array}$ & $\begin{array}{l}\text { Dandekar } \\
\text { RH et al. }\end{array}$ & $\begin{array}{l}\text { Rajashree } \\
\text { Ket al. }\end{array}$ \\
\hline $\begin{array}{l}\text { Prevalence } \\
\text { of LBW }\end{array}$ & $22 \%$ & $11.67 \%$ & $31.3 \%$ \\
\hline
\end{tabular}

In Table 5 some of the early Newborn care practices which were given immediately after birth are shown. 55.6 $\%$ of the mothers told mucous extractor was used to clean respiratory passage and about $44.4 \%$ of the mothers did not know whether the respiratory passage was cleaned or not. About $50.6 \%$ of the mothers did not know how the eyes were cleaned and remaining mothers told sterile cotton was used to clean the eyes. In our study it is showed that, $98.7 \%$ used sterile blade and $100 \%$ used umbilical cord clamp for cord care and nothing was applied to the cord stump. $94.4 \%$ cleaned with dry cloth. Because of $100 \%$ institutional deliveries in our field practice area, the care given to Newborn was good.

In a newborn care study in Meerut, it was reported that, only $50 \%$ of the newborns received complete cord care (new blade, new thread and nothing applied to the cord) almost all 93\% mothers reported that the cord was cut only after the placenta was delivered. ${ }^{16}$

Sharma RK et al stated that in tribal areas of Madhya Pradesh, umbilical cord is cut with the blade or sickle in most of the cases. In some tribes, cord is cut by bamboo piece or arrow-head in case of male child and by a knife or blade in case of female child. After delivery both 
mother and baby take bath with warm water mixed with turmeric. The child is also given a massage with locally available oil (mustard or tore oil) and child is kept warm through indigenous methods. Firewood is lit at the place of seclusion, which keeps the place warm. ${ }^{17}$

Table 10: Relationship between the Mothers literacy status and Breast feeding initiation.

\begin{tabular}{|c|c|c|c|}
\hline \multirow{2}{*}{ Literacy status } & \multicolumn{2}{|c|}{ Breast feeding initiated } & \multirow{2}{*}{ Total } \\
\hline & $<1$ hour & $>1$ hour & \\
\hline Illiterates & $15(75 \%)$ & $5(25 \%)$ & $20(100 \%)$ \\
\hline Literates & $85(60.7 \%)$ & $55(39.3 \%)$ & $140(100 \%)$ \\
\hline Total & $100(62.5 \%)$ & $60(37.5 \%)$ & $160(100 \%)$ \\
\hline
\end{tabular}

The observation in our study showed that $62.5 \%$ of the mothers initiated breast feeding within 1 hour of birth. In
India the rate of initiation of breast feeding within 1 hour of birth in rural areas is only $22.4 \%$ (NFHS-3). ${ }^{8}$

Madhu $\mathrm{K}$ et al study of breast feeding practices and newborn care in rural areas, shows that most of the mothers initiated breastfeeding (97\%) and the other 3\% were not able to initiate due to separation from mother or due to advice from the mother-in-law. ${ }^{18}$

Table 11: Eligibility for JSY.

\begin{tabular}{|llll|}
\hline \multirow{2}{*}{ Caste } & \multicolumn{3}{l}{ BPL card holding families } \\
& Yes & No & Total \\
\hline SC & 29 & 17 & 46 \\
\hline ST & 9 & 3 & 12 \\
\hline Others & 51 & 51 & 102 \\
\hline Total & 89 & 71 & 160 \\
\hline
\end{tabular}

Table 12: Relation between the Literarcy status of the mother and their awareness about ASHA worker, 24/7 PHC and JSY scheme.

\begin{tabular}{|c|c|c|c|c|c|}
\hline \multicolumn{2}{|c|}{ Awareness about } & Illiterate & Literate & Total & p valvue (Fisher's Exact Test) \\
\hline \multirow{2}{*}{ ASHA worker } & Yes & 18 & 115 & 133 & \multirow[b]{2}{*}{$\mathrm{p}=0.531$} \\
\hline & No & 2 & 25 & 27 & \\
\hline \multirow{2}{*}{$24 / 7$ hospitals } & Yes & 19 & 139 & 158 & \multirow{2}{*}{$\mathrm{p}=0.235$} \\
\hline & No & 1 & 1 & 2 & \\
\hline \multirow{2}{*}{ JSY } & Yes & 13 & 96 & 109 & \multirow{2}{*}{$\mathrm{p}=0.799$} \\
\hline & No & 7 & 44 & 51 & \\
\hline
\end{tabular}

There are $156(97.5 \%)$ women were aged 19 years and above. From the above table it shows that there are 109 $(68.1 \%)$ women eligible for JSY. Among these eligible mothers only $56(51.4 \%)$ women have recieved cash incentive under JSY. The reason is that not availability of funds to issue cheque in time.

It can be concluded that irrespective of the literacy status majority of the women were aware about ASHA worker, 24/7 hospital and JSY scheme. Same is shown by Fisher's Exact Test, that there is no statistical association between the literacy status and others $(\mathrm{p}=0.531, \mathrm{p}=0.235 \mathrm{p}$ $=0.799$ ). From this we can say that health workers (ANM and ASHA) are working efficiently in our study settings.

According to Table 11 and 12. Beneficiaries for JSY Scheme were 109 individuals of them $100 \%$ awareness was present regarding the scheme.

\section{ACKNOWLEDGEMENTS}

Author would like to thank the Dean and Director Dr. Devadass P K, Professor and Head Dr Ranganath TS for the opportunity \& support, Dr Ravish KS for his guidance, Faculty, my fellow Post Graduates and Staff of PHC, Hesarghatta.

Funding: No funding sources

Conflict of interest: None declared

Ethical approval: The study was approved by the Institutional Ethics Committee

\section{REFERENCES}

1. Thomas S. A Study to compare the knowledge and practices of postnatal mothers regarding neonatal care from selected urban and rural settings of Bangalore. 2005;1-119. Available at: www.dspacerguhs.ac.in. Accessed on 2 June, 2016.

2. UNICEF. Committing to child survival : a promise renewed. UNICEF progress report 2012. Available at; http://www.unicef.org/publications/index_65820.ht ml. Accessed on 4 July, 2016.

3. World Health Organization. The world health report 1998: life in the $21^{\text {st }}$ century A vision for all. World Heal Organ. 1998;226. Available at: http://www.who.int/whr/1998/media_centre/50facts/ en/\#\nhttp://bases.bireme.br/cgibin/wxislind.exe/iah/online/?IsisScript=iah/iah.xis\& 
src $=$ google $\&$ base $=$ PAHO\&lang $=$ p\&nextAction $=\operatorname{lnk}$ \&exprSearch=25006\&indexSearch=ID. Accessed on 4 July, 2016.

4. Ahmad S, Goel K, Agarwal G, Goel P, Kumar V, Prakash A. community medicine \& health education assessment of the newborn care practices in home deliveries among urban slums of Meerut, UP India. 2012;2(8):8-11.

5. Sreeramareddy CT, Joshi HS, Sreekumaran B V, Giri S, Chuni N. Home delivery and newborn care practices among urban women in western Nepal: a questionnaire survey. BMC Pregnancy Childbirth. 2006;6:27.

6. Yasmin S, Osrin D, Paul E, Costello A. Neonatal mortality in low birth weight infants in Bangladesh. Bull World Health Organ. 2001;79(7):608-14.

7. Maternal and newborn care practices among the urban poor in Indore, India. Development. 2007; Available from: http://uhrc.in/downloads/Reports/MNH_REPORTAugust-2007.pdf. Accessed on 4 July, 2016.

8. Government of India. NFHS-3. Gov India. 18:29. Available at: http://www.rchiips.org/nfhs/pdf/India.pdf. Accessed on 4 July, 2016.

9. District Level Household and Facility Survey -4 State Fact Sheet Karnataka [Internet]. 2012. Available from: https://nrhmmis.nic.in/DLHS4/Karnataka/Karnataka.pdf

10. District level household and facility survey -4 district fact sheet. 2012. Available from: https://nrhm-mis.nic.in/DLHS4/Karnataka/District Factsheets/Bangalore Rural.pdf. Accessed on 4 July, 2016.

11. Puri S, Bhatia V, Sharma M, Swami H, Magnat C. Comparison of prevalent newborn rearing practices, in urban and slum population of chandigarh, UP, India. Intern J Pediatr Neonatol. 2007;9(1):25-7.

12. Gandhi SJ, Godara N, Modi A, KanthariaSL. Newborn care practices of mothers in rural areas of Navsari district. Int $\mathbf{J}$ Med Sci Public Heal. 2014;3(7):1. Available at: http://www.scopemed.org/?mno=163468. Accessed on 4 July, 2016.

13. Child Health Report, MOHFW. 2006. Available at: http://hetv.org/india/nfhs/nfhs3/NFHS-3-Chapter09-Child-Health.pdf. Accessed on 4 July, 2016.

14. Dandekar RH, Shafee M, Sinha SP. Prevalence and risk factors affecting low birth weight in a district hospital at Perambalur, Tamilnadu.

15. Rajashree K, Prashanth HL, Revathy R. Study on the factors associated with low birth weight among newborns delivered in a tertiary-care. 2015;4(9):1287-90.

16. USAID. Newborn Care scenario in the slums of Meerut, Uttar Pradesh : Implications for Program \& Policy. Available at; http://uhrc.in/downloads/New_Born_Care_Fact_She et.pdf. Accessed on 4 July, 2016.

17. Sharma R. Newborn health among tribes of Madhya Pradesh-an Overview. RMRCT Updat e. 2007;4(1):1-12.

18. Madhu K, Chowdary S, Masthi R. Breast feeding practices and newborn care in rural areas: a descriptive cross-sectional study. Indian J Community Med. 2009;34(3):243-6.

Cite this article as: Narasimha BC, Ravish KS, Ranganath TS, Manjula K, Spoorthy S, Navya SS. An assessment of effect of national rural health mission on newborn care practices in Bangalore rural area. Int $\mathbf{J}$ Community Med Public Health 2016;3:2377-80. 